\title{
PERLINDUNGAN HUKUM TERHADAP PEMEGANG HAK MEREK: SUATU KAJIAN KOMPARATIF ANTARA JEPANG DAN INDONESIA
}

\author{
Nopiana $^{1}$, Hari Sutra Disemadi ${ }^{2}$ \\ ${ }^{1}$ Fakultas Hukum, Universitas Internasional Batam, Indonesia, 1851141.nopiana@uib.edu \\ ${ }^{2}$ Fakultas Hukum, Universitas Internasional Batam, Indonesia, hari@uib.ac.id
}

\begin{abstract}
Industrial revolution 4.0 causes everyone to compete to produce work. One of the things that play an important role in this industry is a brand. The term brand is familiar in society, every day we use many products with various brands. This is where the presence of a brand is needed to differentiate the products that have been produced. Brands also make it easy for consumers to identify the products they want. With the increasing number of products on the market today, it is necessary to regulate the brand. Everyone is indeed free to work, but that freedom is also often violated. Therefore, as a part of intellectual property, the brand must get protection. So, this research aims to compare the protection of brands between Japan and Indonesia. This study uses a normative legal research method with a statutory approach and a comparative law approach. Indonesia already has a legal instrument that regulates trademark protection, namely Law no. 20 of 2016. The same is done by Japan. They have also provided protection to their citizens about trademark rights. This is stipulated in the Japan Trademark Act.
\end{abstract}

\section{ARTICLE INFO}

\section{Keywords:}

Comparison; Trademark

Rights; Indonesia; Japan

\section{Cite this paper:}

Nopiana, H. S. (2021).

Perlindungan Hukum

Terhadap Pemegang Hak

Merek: Suatu Kajian

Komparatif Antara Jepang

Dan Indonesia. Widya

Yuridika: Jurnal Hukum.

\section{Scope Article}

Human Rights

\section{PENDAHULUAN}

Selama satu dekade terakhir, pemerintah Indonesia telah memperkenalkan serangkaian reformasi kelembagaan yang bertujuan untuk menciptakan sistem ekonomi yang berorientasi pada pasar. Di sektor hukum, Indonesia telah memperkenalkan beberapa undang-undang ekonomi baru di berbagai bidang khususnya di bidang kekayaan intelektual. Reformasi kelembagaan perlu dipahami dalam konteks politik dan sosial, paling tidak dalam kasus Indonesia, khususnya dalam konteks tekanan struktural yang muncul dari ekonomi politik global. Reformasi kelembagaan disini merujuk pada penciptaan apa yang disebut sebagai institusi ramah pasar dalam masyarakat. Secara khusus, ini mengacu pada penciptaan struktur kelembagaan yang menyediakan lingkungan yang lebih aman untuk hak kepemilikan dalam masyarakat. Atas dasar ini, ia berpendapat bahwa alasan utama masyarakat barat telah tumbuh jauh lebih kuat dibandingkan dengan masyarakat yang ada di dunia ketiga dalam beberapa dekade terakhir adalah karena masyarakat barat telah belajar untuk menciptakan lembaga yang efisien dan mendorong pertumbuhan ekonomi. ${ }^{1}$

${ }^{1}$ Rosser, AQ. "The Political Economy of Institutional Reform in Indonesia". Law, Capitalism and Power in Asia: The Rule of Law and Legal Institutions (1999): 95-117., hlm. 96. 
Terlebih lagi saat ini pertumbuhan penduduk berada di angka yang tinggi. Akibatnya, apabila tidak diimbangi dengan produktivitas yang tinggi, maka pertumbuhan ekonomi juga akan terhambat. $^{2}$

Selain itu, revolusi industri 4.0 telah menggiring manusia ke peradaban yang sangat terpengaruh dengan teknologi dan informasi. ${ }^{3}$ Melalui pengetahuan yang dimilikinya, manusia dapat menghasilkan berbagai macam karya dalam rangka menjaga kelangsungan hidupnya. Tidak mengherankan bahwa saat ini setiap orang dan setiap negara sedang berlomba-lomba untuk menghasilkan karya-karya besar. Hal tersebut tak lain ditujukan untuk memperoleh pengakuan dan penghormatan dari negara-negara lain. Semakin kompetitifnya persaingan antar negara di dunia menyebabkan industri perdagangan menjadi berkembang begitu pesat. Sehingga, produk-produk yang dihasilkan pun sangat berlimpah di pasar. Untuk memberi perbedaan antara produk yang beredar di pasar, perusahaan-perusahaan di dunia telah memiliki berbagai macam tanda dengan ciri khasnya masing-masing. Tanda yang dimaksud untuk membedakan produk-produk tersebut disebut sebagai merek. Merek juga dapat difungsikan untuk memberikan pencegahan terhadap persaingan-persaingan usaha yang tidak sehat. ${ }^{4}$ Secara sederhana, merek dapat diartikan sebagai tanda yang memberi perbedaan antara produk ataupun jasa yang dihasilkan antara satu produsen dengan produsen lainnya. Tanda tersebut dapat berbentuk tiga dimensi maupun dua dimensi. Merek ditampilkan dalam bentuk desain grafis yang memiliki karakteristik dan warna yang berbeda-beda. Masing-masing produsen atau perusahaan memiliki ciri khasnya masing-masing dalam membentuk merek yang mereka inginkan. ${ }^{5}$ Dengan demikian, setiap orang khususnya yang terlibat dalam industri perdagangan diberikan kebebasan untuk memperkenalkan mereknya masing-masing. Hal ini dimaksudkan agar merek tersebut semakin dikenal oleh masyarakat luas. Mengingat, saat ini masyarakat memiliki ketertarikannya sendiri terhadap merek-merek tertentu. Karena kehadiran merek akan memudahkan konsumen untuk menilai kualitas dari sebuah produk. ${ }^{6}$ Merek yang banyak dikenal oleh masyarakat tentu akan menghasilkan keuntungan yang besar.

Hak merek yang tidak terlepas dari bagian hak kekayaan intelektual itu sendiri telah menjadi pusat perhatian masyarakat dunia sejak dikeluarkannya Intellectual Property Rights oleh GATT.7 Tujuannya adalah sebagai suatu bentuk perlindungan, penghormatan, dan kepastian hukum bagi masyarakat internasional di bidang kekayaan intelektual. Mengingat, terdapat hak dan kewajiban yang tercantum dalam hukum internasional. Sebagai salah satu masyarakat internasional, Indonesia juga telah memberikan jaminan kepastian hukum kepada seluruh warga negaranya dalam hal kekayaan intelektual. Hal tersebut diwujudkan dalam bentuk "Undang-Undang Nomor 20 Tahun 2016 tentang Merek dan Indikasi Geografis (UU Merek \& Indikasi Geografis)". Dengan demikian, ada harapan yang besar bahwa instrumen hukum nasional tersebut dapat memberikan perlindungan, pencegahan, dan penindakan terhadap pelanggaran-pelanggaran merek di Indonesia. ${ }^{8}$ Kemudian, sebagai salah satu negara yang menguasai industri perdagangan dunia, Jepang juga memberikan perhatian yang serius terhadap merek. Bagaimana tidak, sudah banyak sekali produk Jepang

\footnotetext{
2 Putong, Iskandar, and Nuring Dyah Andjaswati. "Pengantar Ekonomi Makro”. Jakarta: Mitra Wacana Media (2010)., hlm. 7.

3 Syarief, Elza, et al. "Potensi Terjadinya Persaingan Usaha Tidak Sehat pada Penggunaan Aplikasi Perdagangan Elektronik di Era Revolusi Industri 4.0." Jurnal Supremasi (2021): 105-114., hlm. 107.

4 Faradz, Haedah. "Perlindungan Hak Atas Merek". Jurnal Dinamika Hukum 8.1 (2008): 38-42., hlm. 39.

5 Shaleh, Ali Ismail, and Shabirah Trisnabilah. "Perlindungan Hukum Terhadap Persamaan Merek Untuk Barang Atau Jasa Yang Sejenis: Studi Merek Bossini." Journal of Judicial Review 22.2 (2020): 291-300., hlm, 295.

${ }^{6}$ Karina, Rahmadia Maudy Putri, and Rinitami Njatrijani. "Perlindungan Hukum Bagi Pemegang Hak Merek Dagang Ikea Atas Penghapusan Merek Dagang”, Jurnal Pembangunan Hukum Indonesia 1.2 (2019): 194-212., hlm. 195.

7 Pratama, Toebagus Galang Windi. "Perbandingan Sistem Pendaftaran Merek Negara Indonesia Dengan Zimbabwe”. Jurnal Meta-Yuridis 1.1 (2018)., hlm. 62

8 Disemadi, Hari Sutra, and Wiranto Mustamin. "Pembajakan Merek Dalam Tatanan Hukum Kekayaan Intelektual Di Indonesia." Jurnal Komunikasi Hukum (JKH) 6.1 (2020): 83-94., hlm. 87.
} 
yang beredar di pasar nasional dan internasional. Sebut saja merek industri otomotif seperti honda, suzuki, dan toyota yang banyak digunakan khususnya oleh masyarakat Indonesia. Oleh karena itu, dibutuhkan instrumen hukum yang dapat dijadikan sebagai payung hukum terhadap potensi pelanggaran-pelanggaran merek dagang di Jepang. Instrumen hukum yang sekarang berlaku di Jepang dan dijadikan sebagai instrumen hukum terhadap merek adalah Japan Trademark Act. Sehingga, pada tulisan ini penulis memiliki maksud dan tujuan untuk memberikan identifikasi terhadap perbandingan pengaturan hak mereka antara negara Jepang dan Indonesia.

\section{METODE}

Penelitian ini dilakukan dengan menggunakan metode penelitian yuridis-normatif dengan pendekatan perbandingan hukum serta pendekatan perundang-undangan. Metode ini sesuai dengan maksud dan tujuan penelitian, yaitu untuk membandingkan pengaturan regulasi mengenai hak merek antar negara, dalam hal ini adalah antara negara Indonesia dan negara Jepang. Oleh karena itu, bahan-bahan yang terdapat dalam tulisan ini bersumber dari bahan hukum sekunder, yaitu buku, jurnal, artikel ilmiah, dan peraturan perundangundangan dijadikan sebagai rujukan hukum. Undang-undang yang akan digunakan dalam penelitian ini adalah UU Merek \& Indikasi Geografis dan Japan Trademark Act. Kemudian, logika yang digunakan oleh penulis dalam penelitian normatif adalah dengan cara mengaitkan bahan hukum sekunder, yurisprudensi, dan doktrin. ${ }^{9}$ Sehingga, dapat dikatakan bahwa penelitian normatif menggunakan logika yang deduktif, artinya kebenaran dari pernyataan dalam sebuah judul berlaku umum. ${ }^{10}$

\section{HASIL DAN PEMBAHASAN}

\section{Perlindungan Hukum Terhadap Pemegang Hak Merek di Indonesia a) Konsep Dasar Hak Merek di Indonesia}

Melalui UU Merek \& Indikasi Geografis, maka dapat dinilai bentuk kesadaran dari Pemerintah Indonesia terhadap konvensi-konvensi internasional yang secara tegas telah mengatur tentang perlindungan hak merek bagi masyarakat internasional. Selain itu, UU Merek \& Indikasi Geografis juga merupakan instrumen hukum yang diharapkan dapat memberikan pelayanan kepada masyarakat Indonesia di bidang merek. UU Merek \& Indikasi Geografis pun telah memberikan definisi secara yuridis mengenai apa pengertian merek. Merek memang tidak berwujud secara materil, ia hanya ditempelkan pada suatu produk yang jual dipasaran. ${ }^{11}$ Namun, merek menjadi sangat penting karena ketika konsumen menggunakan sebuah produk, maka yang dinilai adalah mereknya. Seorang konsumen tentu akan merasa puas terhadap merek tertentu jika barang atau produk yang dibeli sesuai dengan kualitas yang diinginkannya. Merek dagang tidak selalu memberikan informasi tentang komposisi atau karakteristik suatu produk. Namun, konsumen dapat memperoleh informasi tentang kualitas suatu produk berdasarkan pengalaman mereka sendiri atau pengalaman orang lain. Sehingga, merek dagang dapat melindungi kepentingan publik karena memungkinkan konsumen mengidentifikasi merek yang dihormati dan menurut mereka aman. ${ }^{12}$ Dengan demikian, konsumen akan dapat mengenali produk yang mereka inginkan tanpa harus membedakan antara produk atau mencoba menentukan produk mana yang mengidentifikasi dan memenuhi kebutuhan dan preferensi mereka. Perlindungan

\footnotetext{
${ }_{9}^{9}$ Benuf, Kornelius, and Muhamad Azhar. "Metodologi Penelitian Hukum sebagai Instrumen Mengurai Permasalahan Hukum Kontemporer." Gema Keadilan 7.1 (2020): 20-33., hlm. 27.

10 Diantha, I Made Pasek. Metodologi Penelitian Hukum Normatif Dalam Justifikasi Teori Hukum. Prenada Media, (2016)., hlm. 121.

11 Firmansyah, Hery. Perlindungan Hukum Terhadap Merek: Panduan Memahami Dasar Hukum Penggunaan dan Perlindungan Merek. Media Pressindo, (2018)., hlm. 30.

12 Amboro, F. Yudhi Priyo. "Problematika Pendaftaran Merek Untuk Usaha Mikro, Kecil dan Menengah di Kota Batam." Journal of Judicial Review 21.1 (2019): 1-14., hlm. 9.
} 
konsumen atas dasar undang-undang merek dagang melindungi konsumen dari disinformasi dengan meminimalkan risiko disesatkan. ${ }^{13}$

Pada dasarnya, hak merek merupakan hak yang diberikan secara eksklusif. Oleh karena itu, hak merek masih termasuk ke dalam hak kebendaan yang dapat dialihkan kepemilikannya kepada orang lain. ${ }^{14}$ Bukti kepemilikan terhadap merek tersebut dibuktikan dengan sertifikat hak merek. Untuk mendapatkannya, maka pihak yang membuat merek tersebut harus mendaftarkannya kepada Direktorat Jenderal Kekayaan Intelektual Indonesia. Pencatatan merek tersebut ditujukan untuk mendapatkan kepastian hukum. Sebagai negara yang cenderung mengadopsi sistem hukum civil law, maka bukti di atas kertas menjadi sangat penting. Mengingat, potensi akan terjadinya sengketa antara para pihak terhadap suatu kepemilikan merek masih tergolong cukup besar. Pengakuan terhadap merek oleh Direktorat Jenderal Kekayaan Intelektual diberikan kepada pihak yang mendaftarkan merek tersebut untuk pertama kalinya. Dengan kata lain, Indonesia mengadopsi sebuah sistem yang disebut sebagai first to file. ${ }^{15}$

Saat ini, merek menjadi sebuah aset yang begitu penting bagi produsen atau perusahaan. Baik atau tidaknya reputasi perusahaan saat ini bergantung pada merek yang dibangun oleh perusahaan tersebut. ${ }^{16}$ Oleh karena itu, untuk membangun sebuah merek agar dikenal oleh masyarakat tidak lah mudah. Biaya yang sangat besar dan waktu yang tidak sedikit menjadi pengorbanan yang harus diberikan secara sukarela oleh pelaku bisnis untuk membangun citra merek yang baik dan dikenal masyarakat. Kemudian, terdapat prinsip dasar yang harus dipahami bersama oleh masyarakat jika ingin mendaftarkan mereknya ke Dirjen KI. Untuk memperoleh sebuah hak merek, maka pemohon harus memiliki itikad yang baik. Artinya, merek yang ingin didaftarkan tersebut murni merupakan merek yang dibuat oleh dirinya sendiri. Ia tidak memiliki maksud yang terselubung untuk melakukan duplikasi terhadap merek-merek yang sudah ada sebelumnya. Berdasarkan UU Merek \& Indikasi Geografis, penggunaan Merek diartikan sebagai salah satu syarat mutlak untuk diberikan perlindungan Merek. Apabila dalam 3 tahun merek tidak digunakan, maka akan dihapus dari pendaftaran merek. Apabila merek tersebur tidak pernah digunakan selama 3 tahun bertut turut dalam perdagangan barang ataupun layanan sejak tanggal pendaftaran atau penggunaan terakhir, maka Penghapusan Merek terdaftar dapat diajukan oleh pihak ketiga yang mempunyai kepentingan berupa gugatan kepada Pengadilan Niaga. ${ }^{17}$

Kemudian, yang tidak kalah penting untuk diketahui adalah jangka waktu yang diberikan oleh UU terhadap pemegang hak merek. Berdasarkan undang-undang, perlindungan terhadap hak merek diberikan selama 10 (sepuluh tahun). Selanjutnya, apabila merek tersebut sudah ada selama hampir 10 tahun, maka dapat diperpanjang dengan masa berlaku perlindungan yang sama. ${ }^{18}$ Pembentuk undang-undang memiliki alasan tersendiri yang menyebabkan perlindungan terhadap hak merek lebih pendek dibandingkan dengan hak cipta yang bisa mencapai 70 (tujuh puluh) tahun. Alasannya adalah pembentuk undang-undang menginginkan agar merek yang ada terus digunakan

\footnotetext{
13 Marlyna, Henny, and Agus Sardjono. "Does the Trademark Protection Regulation Protect Consumers against Counterfeit Products? Analyzing the Theories of Trademark and Indonesian Trademark Law." Pertanika Journal of Social Sciences \& Humanities 27.2 (2019)., hlm. 1867.

${ }^{14}$ Hakim, Miftahur Rahman, and Nur Kholidah. "Hak Merek Sebagai Jaminan Gadai Untuk Permodalan Umkm Industri Kreatif Kerajinan Batik". Pena Justisia: Media Komunikasi dan Kajian Hukum 18.2 (2020)., hlm. 83.

15 Sugiarti, Yayuk. "Perlindungan Merek Bagi Pemegang Hak Merek Ditinjau dari Undang-undang Nomor 15 Tahun 2001 Tentang Merek." Jendela Hukum 3.1 (2016): 32-41., hlm. 36.

16 Putra, Fajar Nurcahya Dwi. "Perlindungan hukum bagi pemegang hak atas merek terhadap perbuatan pelanggaran merek." Mimbar Keadilan (2014): 97-108., hlm. 100.

17 Putra, Renggi Ardya. "Legal Possibility to Regulate Defensive Mark as Well-Known Mark Protection In Indonesia." JIPRO: Journal of Intellectual Property 1.1 (2018): 1-12., hlm. 133.

18 Disemadi, Hari Sutra, and Cindy Kang. "Tantangan Penegakan Hukum Hak Kekayaan Intelektual dalam Pengembangan Ekonomi Kreatif di Era Revolusi Industri 4.0." Jurnal Komunikasi Hukum (JKH) 7.1 (2021): 54-71., hlm. 63.
} 
dalam bidang produksi dan distribusi barang maupun jasa. ${ }^{19}$ Sehingga, konsekuensi logisnya adalah undang-undang tidak akan melindungi merek-merek yang tidak pernah digunakan.

\section{b) Penyelesaian Sengketa Hak Merek di Indonesia}

Konflik merupakan salah bagian dari kehidupan manusia yang seringkali sulit untuk dihindari. Termasuk dalam hak merek, walaupun sudah terdapat instrumen hukum yang mengaturnya, intensitas terhadap pelanggaran-pelanggaran hak merek masih tinggi di Indonesia. Pelanggaran-pelanggaran yang kerap kali terjadi adalah berupa duplikasi atau pembajakan dan penggunaan merek milik orang lain tanpa izin. Berbagai upaya telah dilakukan oleh pembentuk undang-undang dalam rangka meminimalisr pelanggaranpelanggaran merek di Indonesia. Jika dilihat dari sisi historisnya, UU Nomor 21 Tahun 1961 tentang Perusahaan dan Merek Perniagaan mengadopsi sistem deklaratif. ${ }^{20}$ Artinya, hak merek melekat pada orang-orang yang pertama kali menggunakan merek tersebut. Kemudian, dalam undang-undang yang terbaru, sistem tersebut diubah. Sistem yang diadopsi oleh undang-undang terbaru adalah sistem konstitutif. Dengan kata lain hak merek diberikan hanya kepada pihak yang pertama kali mendaftarkan mereknya ke Dirjen KI.

Diubahnya sistem tersebut tak lain adalah untuk meminimalisir pelanggaranpelanggaran hak merek di Indonesia. Lebih jelasnya, pendaftaran merek dagang dengan sistem deklaratif memberikan sebuah status bahwa sebelum orang lain dapat membuktikan bahwa ia adalah pemegang hak merek yang sah, maka pendaftaran merek yang pertama lah yang diakui sebagai pengguna pertama. Hal ini berbeda dengan sistem deklaratif, sistem konstitutif, hak merek akan dimunculkan ketika merek tersebut sudah didaftarkan. Oleh karena itu, menurut sistem ini, pendaftaran adalah sebuah keharusan. Berdasarkan sistem deklaratif pada hak merek, penekanan ditempatkan pada penggunaan pertama. Siapapun yang menggunakan merek pertama dianggap sebagai hak hukum atas merek yang bersangkutan. Jadi penggunaan pertama adalah untuk membuat hak merek dagang, bukan pendaftaran. Pendaftaran berfungsi dalam memberikan prasangka hukum, dugaan undangundang bahwa yang mendaftar adalah pengguna pertama, yaitu adalah orang yang berhak atas merek yang bersangkutan. ${ }^{21}$

Kemudian, yang perlu diingat adalah pemegang hak merek juga diberikan hak lain selain mengambil manfaat atas merek tersebut untuk kegiatan produksi barang atau jasa. Hak yang penulis maksud ialah hak untuk mengizinkan pihak lain untuk menggunakan hak mereknya. sehingga mereka dapat menggunakan merek tersebut tanpa melawan hukum. ${ }^{22}$ Izin tersebut dapat disebut juga sebagai lisensi. Apabila ada pihak-pihak yang tidak memiliki izin namun mereka tetap menggunakan merek yang terdaftar secara sah, maka pihak tersebut dapat digugat di Pengadilan Niaga. Lisensi yang dimaksud harus dituangkan dalam perjanjian tertulis antara pemegang hak merek dengan pihak yang akan diberikan izin untuk menggunakan mereknya. Dengan demikian akan timbul perikatan antar kedua belah pihak yang akan menciptakan hubungan hukum. ${ }^{23}$ Sehingga, perjanjian ini lah yang menyebabkan pihak lain dapat menggunakan merek yang telah terdaftar secara sah. Kemudian, Pasal 84 UU Merek \& Indikasi Geografis menyatakan bahwa apabila pemegang hak merek terdaftar merasa bahwa akan ada potensi kerugian yang lebih besar akibat pelanggaran merek yang dilakukan oleh pihak lain, maka ia dapat mengajukan permohonan. Permohonan yang

\footnotetext{
19 Susanto, Yoghi Arief. "Jangka Waktu Perlindungan Hukum Atas Hak Merek Dalam Tinjauan Maslahah Mursalah." Aktualita (Jurnal Hukum) (2020): 416-427., hlm. 421.

20 Dewi, Chandra Gita. Penyelesaian Sengketa Pelanggaran Merek. Deepublish, (2019)., hlm. 4.

${ }^{21}$ Samosir, Prisca Oktaviani, and Aida Mustafa. "Legal Protection Implications on Trademark in Indonesia by Comparing the First to Use and First to File Principles." International Conference on Law Reform (INCLAR 2019). Atlantis Press, (2020):143-146)., hlm. 144.

22 Syarifuddin, Muhammad Setya Ady. "Penyelesaian Sengketa Dalam Perjanjian Lisensi Merek." Simbur Cahaya 26.1 (2019): 27-41., hlm. 30.

23 Setiawan, R. Pokok-Pokok Hukum Perikatan. Bandung: Bardin (1999)., hlm. 2.
} 
dimaksud adalah meminta agar Majelis Hakim agar pihak yang menggunakan hak merek tanpa izin tersebut menghentikan segala kegiatan produksinya.

Berdasarkan undang-undang, maka dapat diketahui bahwa penyelesaian sengketa dalam hak merek diselesaikan melalui pengadilan niaga, alternatif penyelesaian sengketa, dan arbitrase. ${ }^{24}$ Alternatif penyelesaian sengketa merupakan jalur yang dapat ditempuh oleh para pihak dengan cara damai. Kemudian, para pihak juga dapat menyelesaikan sengketanya melalui jalur arbitrase. Namun, untuk penyelesaian melalui jalur ini harus dilandaskan pada perjanjian. ${ }^{25}$ Penyelesaian dengan arbitrase tunduk pada UU No. 30 Tahun 1999. Apabila pihak yang merasa dirugikan ingin menyelesaikan sengketanya melalui jalur litigasi, maka ia harus mengajukan gugatan ke pengadilan niaga. Syarat-syarat dan tata cara pengajuan gugatan telah diatur dalam undang-undang. Sementara itu, apabila pihak tergugat merasa bahwa putusan dari pengadilan niaga belum memenuhi rasa keadilan, maka ia dapat mengajukan kasasi ke Mahkamah Agung. Karena, undang-undang telah menegaskan bahwa upaya hukum terhadap putusan Pengadilan Niaga dapat dilakukan dengan cara mengajukan kasasi.

\section{c) Ketentuan Sanksi Pidana Pelanggaran Merek di Indonesia}

Peraturan perundang- undangan yang ada diIndonesia hampir semua menerapkan sanksi pidana bagi pelaku pelanggaran atau kejahatan. Pidana itu sendiri bertujuan agar seseorang yang melakukan pelanggaran atau kejahatan diharapkan dapat menyadari dan tidak mengulangi kembali kesalahannya serta berubah menjadi orang yang lebih baik. Karena sesungguhnya hukum pidana merupakan hukum sanksi. ${ }^{26}$ Teori Ultimum Remidium menghendaki agar pidana dijadikan sebagai jalan terakhir bagi penyelesaian sebuah masalah atau perkara. ${ }^{27}$ Terhadap perkara yang masuk ke dalam ranah pelanggaran hak merek, sanksi pidana dapat diberlakukan di samping tuntutan ganti rugi akibat pelanggaran hak merek. Namun, tindak pidana pelanggaran yang diatur dalam UU Merek \& Indikasi Geografis merupakan delik aduan. Artinya, masuknya perkara tersebut ke ranah pidana adalah inisiatif dari pemegang hak merek. Jika pemegang hak merek tidak menyampaikan aduannya kepada penyidik, maka pelanggaran tersebut tetap tidak dapat diproses secara yuridis.

Sanksi pidana bagi pelanggaran merek diatur dalam Pasal 100 UU NO 20 Tahun 2016 yang menyebutkan bahwa: Ayat 1: "Setiap Orang yang dengan tanpa hak menggunakan Merek yang sarna pada sejenis yang diproduksi dan/atau diperdagangkan, dipidana dengan pidana penjara paling lama 5 (lima) tahun darr/atau pidana denda paling banyak Rp2.000.000.000,00 (dua miliar rupiah)"; Ayat 2: "Setiap Orang yang dengan tanpa hak rnenggunakan Merek yang mempunyai persamaan pada pokoknya dengan Merek terdaftar milik pihak lain untuk barang dan/atau jasa sejenis yang diproduksi dan/atau diperdagangkan, dipidana dengan pidana penjara paling lama 4 (empat) tahun dan Zatau denda paling banyak Rp2.000.000.000,00 (dua miliar rupiah)"; dan Ayat 3: "Setiap Orang yang melanggar ketentuan sebagaimana dimaksud pada ayat (1) dan ayat (2), yang jenis barangnya mengakibatkan gangguan kesehatan, gangguan lingkungan hidup, darr/atau kematian manusia, dipidana dengan pidana penjara paling lama 10 (sepuluh) tahun dan/atau denda paling banyak Rp5 .000.000.000,00 (lima miliar rupiah)".

Pasal 101 UU Merek \& Indikasi Geografis juga menyebutkan: Ayat 1: “Setiap Orang yang dengan tanpa hak menggunakan tanda yang mempunyai persamaan pada keseluruhan dengan Indikasi Geografis milik pihak lain untuk barang dan atau produk yang sarna atau

\footnotetext{
24 Sembiring, Jimmy Joses. Cara Menyelesaikan Sengketa di Luar Pengadilan. Visimedia, (2011, hlm. 2.

25 Adiputra, I Gede Mahendra Juliana, Ida Ayu Putu Widiati, and Ni Made Puspasutari Ujianti. "Penyelesaian Perkara Pelanggaran Hak atas Merek." Jurnal Preferensi Hukum 1.2 (2020): 67-71., hlm. 70.

26 Moeljatno. "Asas-asas Hukum Pidana". Jakarta: Rineka Cipta (2002)., hlm. 9.

27 Anindyajati, Titis, Irfan Nur Rachman, and Anak Agung Dian Onita. "Konstitusionalitas Norma Sanksi Pidana Sebagai Ultimum Remedium Dalam Pembentukan Perundang-Undangan". Jurnal Konstitusi 12.4 (2016): 872-892. hlm. 874.
} 
sejenis dengan barang danjatau produk yang terdaftar, dipidana dengan pidana penjara paling lama 4 (empat) tahun danjatau denda paling banyak Rp2.000.000.000,00 (dua miliar rupiah)"; dan Ayat 2: "Setiap Orang yang dengan tanpa hak menggunakan tanda yang mempunyai persamaan pada pokoknya dengan Indikasi Geografis milik pihak lain untuk barang danj atau produk yang sarna atau sejenis dengan barang danjatau produk yang terdaftar, dipidana dengan pidana penjara paling lama 4 (empat) tahun danjatau denda paling banyak Rp2.000.000.000,00 (dua miliar rupiah)".

\section{Perlindungan Hukum Terhadap Pemegang Hak Merek di Jepang a) Konsep Dasar Hak Merek di Jepang}

Jepang merupakan negara yang berhasil dalam memanfaatkan diplomasi dalam kebijakan luar negeri mereka. ${ }^{28} \mathrm{Hal}$ ini lah yang menyebabkan Jepang menjadi salah satu negara adidaya yang bersaing dengan negara-negara maju lainnya, Jepang memiliki aktivitas dan perkembangan ekonomi yang sangat pesat. Begitu banyak produk yang dihasilkan oleh para produsen di Jepang, dalam bentuk barang ataupun jasa. Oleh karena itu, dibutuhkan merek agar dapat menjaga persaingan bisnis tetap sehat. Dalam kaitannya dengan perlindungan hak merek, Jepang memiliki sebuah peraturan hukum yang disebut sebagai Japan Trademark Act. Jika ditelusuri, undang-undang tersebut telah mengatur mengenai hak merek dan prosedur pendaftaran hak merek, serta sanksi pidana yang melekat di dalamnya. Dengan kehadiran undang-undang tersebut, diharapkan dapat memberikan kontribusi pada pengembangan industri dan melindungi kepentingan konsumen. Mengingat, merek dagang juga tidak hanya memiliki arti penting bagi produsen, tetapi juga konsumen. ${ }^{29}$ Subjek perlindungan Undang-Undang Merek Dagang adalah merek dagang. Menurut Pasal 1 Japan Trademark Act, tujuan dari Undang-undang ini adalah, melalui perlindungan merek dagang, untuk memastikan pemeliharaan kepercayaan bisnis orang-orang yang menggunakan merek dagang dan dengan demikian untuk berkontribusi pada pengembangan industri dan untuk melindungi kepentingan konsumen. Fungsi atau kegunaan suatu produk barang maupun jasa dapat ditunjukkan dengan hanya dengan sebuah merek. Dengan melindungi reputasi merek yang terkait dengan merek dagang, sistem merek dagang akan melindungi kepentingan konsumen dan berkontribusi pada perkembangan industri.

Kemudian, Japan Trademark Act memberikan perlindungan selama 10 (sepuluh) tahun kepada setiap merek yang didaftarkan. Namun, pemegang hak merek dapat memperpanjangnya setiap 10 (sepuluh) tahun sekali. Pemohon dapat mengajukan permintaan untuk memperbarui merek dagang saat 6 (enam) bulan sebelum masa berlaku perlindungan merek dagang berakhir. Untuk itu, pemohon harus membayar dengan biaya yang sama seperti mendaftarkan merek baru. Japan Trademark Act mendefinisikan merek dagang sebagai setiap karakter, gambar, tanda yang berbentuk tiga dimensi, atau kombinasi daripadanya dengan warna. ${ }^{30}$ Merek dagang yang dimaksud tersebut memiliki fungsi sebagai: 1) digunakan untuk memberikan perlindungan terhadap barang yang diproduksi orang untuk kepentingan bisnis; 2) digunakan untuk memberikan perlindungan kepada orang yang menyediakan layanan atau mengesahkannya sebagai sebuah layanan bisnis.

Selanjutnya, sama seperti ketentuan umum yang ada pada UU Merek \& Indikasi Geografis, Jepang juga memiliki beberapa ketentuan terkait dengan merek yang dilarang penggunaannya. Dalam Pasal 2 Japan Trademark Act, disebutkan beberapa kriteria merek yang tidak boleh didaftaran, diantaranya adalah: 1) Identik dengan, atau mirip dengan, bendera nasional, lambang krisan kekaisaran, hiasan, medali atau bendera nasional asing; 2) Identik dengan, atau mirip dengan, lambang atau lambang negara lain (kecuali bendera nasional dari negara mana pun dari Uni ke Konvensi Paris, anggota Organisasi Perdagangan

${ }^{28}$ Effendi, Tonny Dian. Diplomasi Publik Jepang: perkembangan dan tantangan. Ghalia Indonesia (2011)., hlm. 1.

${ }^{29}$ Ono, Shoen. Overview of Japanese Trademark Law. Yuhikatu, Tokio (1999)., hlm. 1.

30 Ibid., hlm. 2. 
Dunia atau Pihak Penandatangan Perjanjian Hukum Merek Dagang) dari negara Uni ke Konvensi Paris; 3) Identik dengan, atau mirip dengan, tanda yang menunjukkan Perserikatan Bangsa-Bangsa atau organisasi internasional lainnya yang telah ditunjuk oleh Menteri Ekonomi, Perdagangan dan Industri; 4) Identik dengan, atau mirip dengan, lambang atau gelar dalam Pasal 1 Undang-Undang tentang Pembatasan Penggunaan Emblem dan Judul Palang Merah dan Lainnya (Undang-Undang No.159 tahun 1947) atau lambang khas dalam Pasal 158 (1) Undang-Undang tentang Tindakan untuk Melindungi Warga Negara Jepang Selama Serangan Bersenjata dan Lainnya (Undang-Undang No.112 tahun 2004); 5) Terdiri dari tanda yang identik dengan, atau serupa dengan, ciri atau tanda resmi yang menunjukkan kendali atau garansi oleh pemerintah nasional atau lokal Jepang, negara Uni ke Konvensi Paris, anggota Perdagangan Dunia Organisasi atau Pihak pada Perjanjian Hukum Merek Dagang yang telah ditunjuk oleh Menteri Ekonomi, Perdagangan dan Industri; 6) Identik dengan, atau mirip dengan, merek terkenal yang menunjukkan Negara, pemerintah daerah, agennya, organisasi nirlaba yang melakukan bisnis untuk kepentingan umum, atau perusahaan nirlaba yang melakukan bisnis untuk kepentingan umum; dan 7) Dst. (dapat dilihat pada Japan Trademark Act)

\section{b) Pendaftaran Hak Merek di Jepang}

Tidak berbeda dengan Indonesia, perlindungan merek dagang di Jepang mengikuti sistem First to file protection yang berarti semua hak merek dagang yang diperoleh dari pendaftaran merek yang dilakukan pertama kali, bukan dari penggunaannya. ${ }^{31}$ Sehingga, pendaftar pertama lah yang berhak untuk memperoleh hak merek tersebut. ${ }^{32}$ Jika terdapat dua atau lebih permohonan pendaftaran merek yang identik atau serupa, maka, hanya pemohon yang mengajukan permohonan pendaftaran merek pada tanggal yang lebih awal yang berhak untuk didaftarkan. Pada prinsipnya, merek dagang yang dimohonkan pendaftarannya harus digunakan sehubungan dengan barang yang diproduksi oleh perusahaan atau penyedia individu. Kemudian, merek dagang juga tidak dapat didaftarkan jika merek dagang tersebut berpotensi menyebabkan kebingungan tentang suatu barang atau jasa atau kemungkinan akan menyesatkan konsumen sehubungan dengan kualitas barang atau jasa. Pendaftaran merek dagang di Jepang berguna bagi pemilik perusahaan yang baru memulai bisnis dan ingin melindungi identitas perusahaan mereka serta untuk bisnis internasional yang memasuki pasar Jepang.

Berdasarkan Japan Trademark Act, terdapat beberapa syarat atau prosedur diperhatikan dalam melakukan pendaftaran terhadap hak merek, diantaranya adalah: 1) Setiap orang yang ingin mendaftarkan merek dagang harus mengajukan permohonan kepada Komisaris Kantor Paten disertai dengan dokumen yang diperlukan; 2) Komisaris Kantor Paten akan memberikan tanggal pengajuan aplikasi untuk pendaftaran merek dagang sebagai tanggal pengajuan aplikasi yang berkaitan dengannya, kecuali permohonan pendaftaran merek dagang termasuk dalam salah satu dari item pernyataan niat untuk mendaftarkan merek dagang tidak jelas, nama pemohon untuk pendaftaran merek tidak disebutkan atau pernyataannya tidak cukup untuk mengidentifikasi pemohon, merek dagang yang dimintakan pendaftarannya tidak disebutkan dalam aplikasi, dan barang atau layanan yang ditunjuk tidak disebutkan; 3) Jika permohonan pendaftaran merek termasuk dalam salah satu item paragraf sebelumnya, Komisaris Kantor Paten akan meminta orang yang ingin mendaftarkan pendaftaran merek dagang untuk melengkapi aplikasi, menunjuk batas waktu yang wajar untuk tujuan tersebut; 4) Jika seorang pemohon yang diminta untuk melengkapi aplikasi untuk pendaftaran merek dagang berdasarkan ayat (2) Japan Trademark Act melengkapi aplikasi tersebut dalam batas waktu yang ditentukan

\footnotetext{
31 Yanto, Oksidelfa. "Tinjauan Yuridis UU No. 15 Tahun 2001 Tentang Merek: Sisi Lain Kelemahan Sistem First to File Dalam Perlindungan Hukum Atas Merek Sebagai Bagian Dari Hak Atas Kekayaan Intelektual (HaKI)." ADIL: Jurnal Hukum 3.1 (2012): 23-45., hlm. 26.

32 Abdurahman, Humaedi. "Asas Fisrt To File Principal Dalam Kasus Hak Merek Nama Terkenal Bensu." Aktualita (Jurnal Hukum) (2020): 428-443., hlm. 430.
} 
sebagaimana disebutkan dalam paragraf tersebut, Komisaris Kantor Paten harus memberikan tanggal penyerahan Suplemen Tertulis sebagai tanggal pengajuan aplikasi untuk pendaftaran merek dagang; dan 5) Jika pemohon yang telah diminta untuk melengkapi aplikasi untuk pendaftaran merek dagang berdasarkan ayat (2) gagal untuk melengkapi aplikasi tersebut dalam batas waktu yang ditentukan seperti yang disebutkan dalam paragraf tersebut, Komisaris Kantor Paten dapat menolak aplikasi untuk merek dagang tersebut.

\section{c) Ketentuan Sanksi Pidana Pelanggaran Merek di Jepang}

Dalam Japan Trademark Act, terdapat pula ketentuan sanksi pidana yang dimaksudkan untuk menjamin kepastian hukum kepada setiap pemegang hak merek di negara matahari terbit itu. Japan Trademark Act mengklasifikasikan pelanggaran hak merek ke dalam 5 jenis tindak pidana, yaitu: Kejahatan pelanggaran; penipuan; indikasi palsu; sumpah palsu; dan pelanggaran kerahasiaan.

Ketentuan sanksi pidana tersebut diatur dalam Pasal 78-81 Japan Trademark Act. Pasal 78 menyebutkan: (Kejahatan Pelanggaran) "Pelanggar hak merek dagang atau hak eksklusif untuk menggunakan (tidak termasuk orang yang telah melakukan tindakan yang dianggap merupakan pelanggaran hak merek dagang atau hak eksklusif untuk menggunakan

berdasarkan Pasal 37 atau Pasal 67) akan dihukum oleh penjara dengan bekerja untuk jangka waktu tidak lebih dari sepuluh tahun atau denda tidak melebihi 10.000.000 yen atau kombinasi keduanya"; Pasal 79 menyebutkan: (Kejahatan Penipuan) "Setiap orang yang telah memperoleh pendaftaran merek dagang, pendaftaran merek defensif, pendaftaran perpanjangan durasi hak atau hak merek dagang berdasarkan pada pendaftaran merek defensif, keputusan tentang penentangan terhadap pendaftaran atau keputusan pengadilan melalui tindakan penipuan akan dihukum dengan hukuman penjara. bekerja untuk jangka waktu tidak lebih dari tiga tahun atau denda tidak melebihi 3.000.000 yen"; Pasal 80 menyebutkan: (Kejahatan Indikasi Palsu) "Setiap orang yang gagal mematuhi Pasal 74 akan dihukum oleh penjara dengan pekerjaan untuk jangka waktu tidak lebih dari tiga tahun atau denda tidak melebihi 3.000.000 yen"; Pasal 81 menyebutkan: (Kejahatan Sumpah Palsu) "Seorang saksi, saksi ahli atau juru bahasa yang telah mengambil sumpah berdasarkan Undang-Undang ini dan membuat pernyataan palsu atau memberikan pendapat ahli yang salah atau interpretasi yang salah sebelum Kantor Paten atau pengadilan yang ditugaskan demikian, akan dihukum dengan hukuman penjara dengan bekerja untuk jangka waktu antara tiga bulan dan sepuluh tahun"; Pasal 81 ayat (2) menyebutkan: (Kejahatan Pelanggaran Kerahasiaan) "Setiap orang yang gagal mematuhi perintah sesuai dengan Pasal 105-4 (1) (termasuk kasus di mana ia diterapkan secara mutatis mutandis sesuai dengan Pasal 13-2 (5) dari Undang-Undang Paten sebagaimana diterapkan mutatis mutandis sesuai dengan Pasal 39 dari undang-undang ini akan dihukum dengan hukuman penjara dengan pekerjaan untuk jangka waktu tidak lebih dari lima tahun atau denda tidak melebihi 5.000.000 yen atau kombinasi daripadanya".

\section{PENUTUP}

Merek merupakan sebuah tanda atau simbol yang memegang peranan penting dalam industri perdagangan dunia saat ini. Sebagai masyarakat internasional, indonesia pun memberikan penghormatan, pengakuan, serta perlindungan terhadap hak merek. Di Indonesia, terdapat sebuah instrumen hukum yang mengatur tentang hak merek, tata cara pendaftaran, beserta dengan sanksi pidananya. Dalam undang-undang tersebut, pemohon yang ingin mendaftarkan merek dagangnya dapat melakukan permohonan ke Direktorat Jenderal HAKI. Kemudian, penyelesaian sengketa merek di Indonesia dapat dilakukan melalui jalur litigasi, arbitase, maupun alternatif penyelesaian sengketa.

Selanjutnya, di Jepang terdapat sebuah produk legislasi yang mengatur tentang hak merek, yaitu Japan Trademark Act. Pada undang-undang tersebut, diatur mengenai merek- 
merek yang tidak boleh didaftarkan, seperti merek yang identik dengan bendera nasional dan lambang negara. Kemudian, dalam undang-undang tersebut diatur juga tentang tata cara pendaftaran hak merek. Di Jepang, instansi yang memiliki otoritas untuk memberikan hak merek kepada pemohon adalah Komisaris Kantor Paten. Setiap orang yang ingin mendaftarkan merek dagang harus mengajukan permohonan kepada Komisaris Kantor Paten disertai dengan dokumen yang diperlukan. Terdapat satu persamaan yang mencolok antara pendaftaran merek di Jepang dan di Indonesia. Persamaan tersebut adalah mengenai sistem pendaftarannya. Baik di Indonesia maupun Jepang sama-sama mengadopsi sistem first to file. Sehingga, pengakuan terhadap hak merek di kedua negara tersebut ditujukan kepada pihak yang mencatatkan mereknya pertama kali.

\section{DAFTAR PUSTAKA}

Abdurahman, Humaedi. (2020). "Asas Fisrt To File Principal Dalam Kasus Hak Merek Nama Terkenal Bensu." Aktualita (Jurnal Hukum), 428-443.

Adiputra, I Gede Mahendra Juliana, Ida Ayu Putu Widiati, and Ni Made Puspasutari Ujianti. (2020). "Penyelesaian Perkara Pelanggaran Hak atas Merek." Jurnal Preferensi Hukum 1.2: 67-71.

Amboro, F. Yudhi Priyo. (2019). "Problematika Pendaftaran Merek Untuk Usaha Mikro, Kecil dan Menengah di Kota Batam." Journal of Judicial Review 21.1:1-14.

Anindyajati, Titis, Irfan Nur Rachman, and Anak Agung Dian Onita. (2016). "Konstitusionalitas Norma Sanksi Pidana Sebagai Ultimum Remedium Dalam Pembentukan Perundang-Undangan”. Jurnal Konstitusi 12.4: 872-892.

Benuf, Kornelius, and Muhamad Azhar. (2020). "Metodologi Penelitian Hukum sebagai Instrumen Mengurai Permasalahan Hukum Kontemporer." Gema Keadilan 7.1: 2033.

Dewi, Chandra Gita. (2019). Penyelesaian Sengketa Pelanggaran Merek. Deepublish.

Diantha, I Made Pasek. (2016). Metodologi Penelitian Hukum Normatif Dalam Justifikasi Teori Hukum. Prenada Media.

Disemadi, Hari Sutra, and Cindy Kang. (2021). “Tantangan Penegakan Hukum Hak Kekayaan Intelektual dalam Pengembangan Ekonomi Kreatif di Era Revolusi Industri 4.0." Jurnal Komunikasi Hukum (JKH) 7.1: 54-71.

Disemadi, Hari Sutra, and Wiranto Mustamin. (2020). "Pembajakan Merek Dalam Tatanan Hukum Kekayaan Intelektual Di Indonesia." Jurnal Komunikasi Hukum (JKH) 6.1: 8394.

Effendi, Tonny Dian. (2021). Diplomasi Publik Jepang: perkembangan dan tantangan. Ghalia Indonesia.

Faradz, Haedah. (2008). "Perlindungan Hak Atas Merek”. Jurnal Dinamika Hukum 8.1: 38-42.

Firmansyah, Hery. (2018). Perlindungan Hukum Terhadap Merek: Panduan Memahami Dasar Hukum Penggunaan dan Perlindungan Merek. Media Pressindo.

Hakim, Miftahur Rahman, and Nur Kholidah. (2020). "Hak Merek Sebagai Jaminan Gadai Untuk Permodalan Umkm Industri Kreatif Kerajinan Batik". Pena Justisia: Media Komunikasi dan Kajian Hukum 18.2.

Karina, Rahmadia Maudy Putri, and Rinitami Njatrijani. (2019). “Perlindungan Hukum Bagi Pemegang Hak Merek Dagang Ikea Atas Penghapusan Merek Dagang”, Jurnal Pembangunan Hukum Indonesia 1.2: 194-212. 
Marlyna, Henny, and Agus Sardjono. (2019). “Does the Trademark Protection Regulation Protect Consumers against Counterfeit Products? Analyzing the Theories of Trademark and Indonesian Trademark Law." Pertanika Journal of Social Sciences \& Humanities 27.2.

Moeljatno. (2002). Asas-asas Hukum Pidana. Jakarta: Rineka Cipta.

Ono, Shoen. (1999). Overview of Japanese Trademark Law. Yuhikatu, Tokio.

Pratama, Toebagus Galang Windi. (2018). "Perbandingan Sistem Pendaftaran Merek Negara Indonesia Dengan Zimbabwe”. Jurnal Meta-Yuridis 1.1.

Putong, Iskandar, and Nuring Dyah Andjaswati. (2010). "Pengantar Ekonomi Makro". Jakarta: Mitra Wacana Media.

Putra, Fajar Nurcahya Dwi. (2014). "Perlindungan hukum bagi pemegang hak atas merek terhadap perbuatan pelanggaran merek." Mimbar Keadilan: 97-108.

Putra, Renggi Ardya. (2018). "Legal Possibility to Regulate Defensive Mark as Well-Known Mark Protection in Indonesia.” JIPRO: Journal of Intellectual Property 1.1: 1-12.

Rosser, AQ. (1999). "The Political Economy of Institutional Reform in Indonesia". Law, Capitalism and Power in Asia: The Rule of Law and Legal Institutions: 95-117.

Samosir, Prisca Oktaviani, and Aida Mustafa. (2020). "Legal Protection Implications on Trademark in Indonesia by Comparing the First to Use and First to File Principles." International Conference on Law Reform (INCLAR 2019). Atlantis Press, :143-146.

Sembiring, Jimmy Joses. (2011). Cara Menyelesaikan Sengketa di Luar Pengadilan. Visimedia.

Setiawan, R. (1999). Pokok-Pokok Hukum Perikatan. Bandung: Bardin.

Shaleh, Ali Ismail, and Shabirah Trisnabilah. (2020). "Perlindungan Hukum Terhadap Persamaan Merek Untuk Barang Atau Jasa Yang Sejenis: Studi Merek Bossini." Journal of Judicial Review 22.2: 291-300.

Sugiarti, Yayuk. (2016). "Perlindungan Merek Bagi Pemegang Hak Merek Ditinjau dari Undang-undang Nomor 15 Tahun 2001 Tentang Merek." Jendela Hukum 3.1: 32-41.

Susanto, Yoghi Arief. (2020). “Jangka Waktu Perlindungan Hukum Atas Hak Merek Dalam Tinjauan Maslahah Mursalah." Aktualita (Jurnal Hukum): 416-427.

Syarief, Elza, et al. (2021). "Potensi Terjadinya Persaingan Usaha Tidak Sehat pada Penggunaan Aplikasi Perdagangan Elektronik di Era Revolusi Industri 4.0." Jurnal Supremasi: 105-114.

Syarifuddin, Muhammad Setya Ady. (2019). “Penyelesaian Sengketa Dalam Perjanjian Lisensi Merek." Simbur Cahaya 26.1: 27-41.

Yanto, Oksidelfa. (2012). “Tinjauan Yuridis UU No. 15 Tahun 2001 Tentang Merek: Sisi Lain Kelemahan Sistem First to File Dalam Perlindungan Hukum Atas Merek Sebagai Bagian Dari Hak Atas Kekayaan Intelektual (HaKI)." ADIL: Jurnal Hukum 3.1: 23-45., hlm. 26. 


\section{Peraturan Perundang-undangan}

Japan Trademark Act.

Undang-Undang Nomor 20 Tahun 2016 tentang Merek dan Indikasi Geografis.

Undang-Undang Nomor 21 Tahun 1961 tentang Perusahaan dan Merek Perniagaan

Undang-Undang Nomor 30 Tahun 1999 tentang Arbitrase dan Alternatif Penyelesaian Sengketa. 